BIODIK: Jurnal IImiah Pendidikan Biologi
ISSN 2580-0922 (online), ISSN 2460-2612 (print)
Volume 07, Nomor 04, Tahun 2021, Hal. 95-106
Available online at:
https://online-journal.unja.ac.id/biodik

Research Article

OPEN

ACCESS

\title{
Analisis Kejenuhan dan Minat Belajar Siswa dalam Pembelajaran Daring pada Pelajaran Biologi di SMAN 1 Unggulan Muara Enim
}

\author{
(Analysis of Students' Saturation and Learning Interest in Online Learning in \\ Biology Lessons at SMAN 1 Unggulan Muara Enim)
}

\author{
Meta Rulita*, Sri Wardhani, Astrid S.W. Sumah \\ Program Pascasarjana Pendidikan Biologi,Universeitas Muhammadiyah Palembang \\ Jl. Jendral Ahmad Yani, Kel. 13 Ulu. Kec. Seberang Ulu II, Palembang, Sumatera Selatan, 30263 \\ *Corresponding Author: metarulita099@gmail.com
}

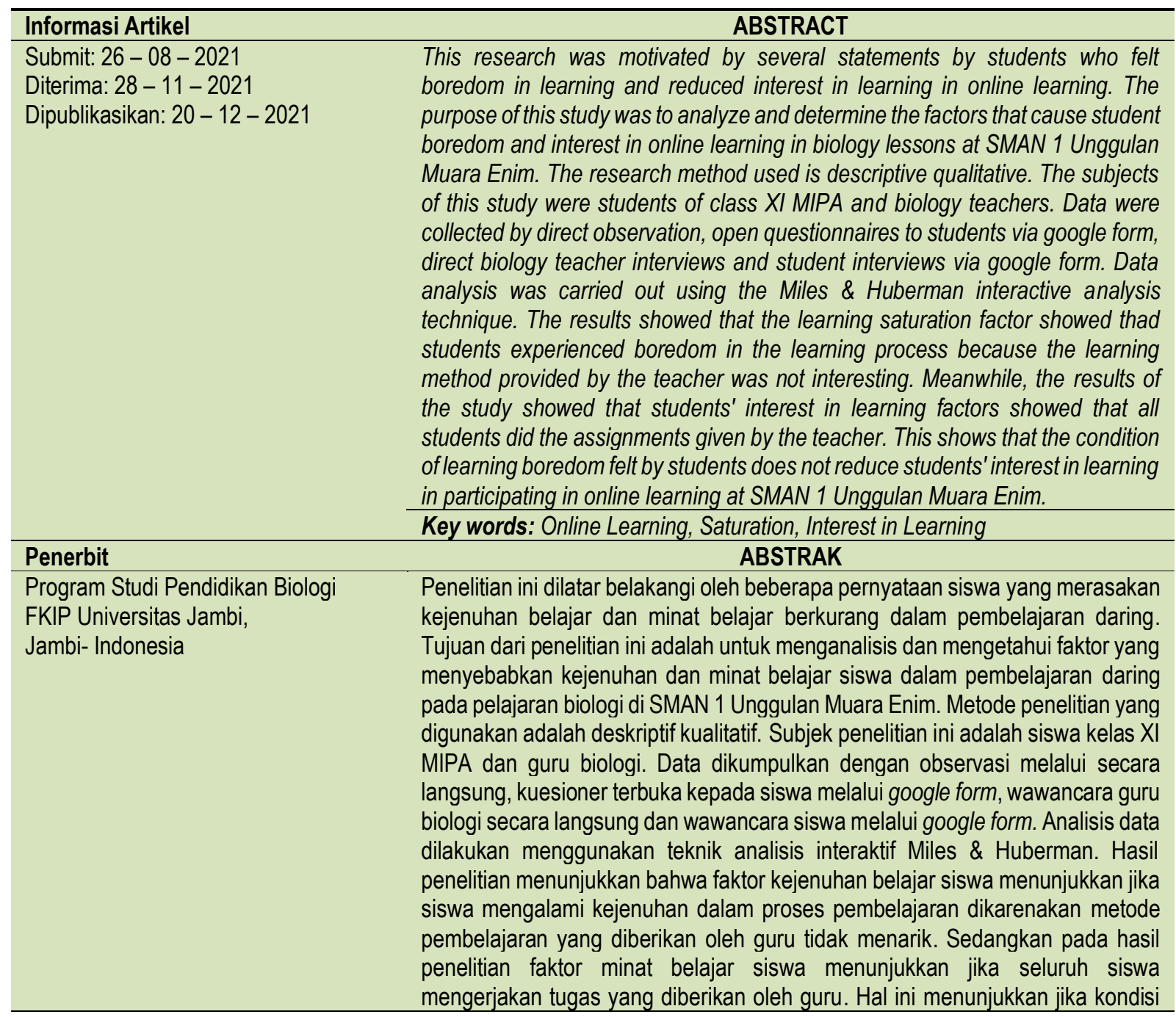


kejenuhan belajar yang dirasakan oleh siswa tidak menurunkan minat belajar siswa dalam mengikuti pembelajaran daring di SMAN 1 Unggulan Muara Enim. Kata kunci: Pembelajaran Daring, Kejenuhan, Minat Belajar

c) (1) (2)

BY NE SA

This BIODIK : Jurnal IImiah Pendidikan Biologi is licensed under a CC BY-NC-SA (Creative Commons Attribution-ShareAlike 4.0 International License)

\section{PENDAHULUAN}

Pandemi Corona virus Disease 2019 (Covid-19) memberikan dampak pada banyak pihak dan telah merambah pada dunia pendidikan. Pemerintah memberikan kebijakan untuk meliburkan seluruh lembaga pendidikan dapat meminimalisir penyebaran pandemi Covid-19 berdasarkan surat edaran dari Menteri Pendidikan dan Kebudayaan Nomor 36962/MPK.A/HK/2020 tertanggal 17 Maret 2020 tentang pembelajaran secara daring (Anugrahana, 2020). Pembelajaran daring adalah metode belajar yang menggunakan model interaktif berbasis Internet (Malyana, 2020). Situasi ini tentunya memberikan dampak pada pembelajaran yang tidak dapat dihindari ketika melakukan kegiatan belajar baik di sekolah maupun di rumah yaitu adanya suatu masalah. Salah satu masalah yang biasa dihadapi ketika melakukan pembelajaran secara daring yaitu timbulnya kejenuhan belajar (Arifa. F. N., 2020).

Kejenuhan belajar adalah suatu kondisi mental seseorang saat mengalami rasa bosan dan lelah yang amat sangat sehingga mengakibatkan timbulnya rasa lesuh dan tidak bersemangat untuk melakukan aktivitas belajar (Dewi et al., 2017). Faktor yang menyebabkan kejenuhan belajar yang kerap melanda siswa yaitu media pembelajaran yang kurang mendukung dalam proses belajar, terlalu banyak hafalan, terlalu banyak tugas dan tekanan mata pelajaran lainnya sehingga siswa mengalami kejenuhan belajar (Damayanti et al., 2020). Berdasarkan penelitian terdahulu oleh (Kurnia, 2021) menyatakan bahwa siswa memiliki kelelahan emosi yang tinggi pada proses belajar online. Berdasarkan penelitian yang dilakukan oleh (Isfahani et al., 2021) menyatakan treatment skor pada pre-test dapat menurunkan kejenuhan belajar menjadi sebesar $69 \%$.

Selain kejenuhan belajar, faktor lain yang mempengaruhi adalah minat belajar. Minat belajar adalah salah satu rasa untuk menyukai atau ketertarikan pada satu hal dan aktivitas belajar tanpa ada yang menyuruh untuk belajar (Ricardo \& Meilani, 2017). Minat untuk belajar memiliki peran yang besar, karena minat belajar siswa merupakan faktor utama yang akan menentukan keaktifan siswa (Berutu \& Tambunan, 2018). Bila bahan pelajaran yang dipelajari tidak sesuai dengan minat siswa, maka siswa tidak akan belajar dengan sebaik-baiknya. Oleh karena itu, untuk mengatasi siswa yang kurang berminat dalam belajar, guru hendaknya berusaha bagaimana menciptakan kondisi tertentu agar siswa memiliki terus belajar (Sirait, 2016).

SMAN 1 Unggulan Muara Enim sebagai tempat penelitian karena SMAN 1 Unggulan Muara Enim adalah SMA terbaik di Kota Muara Enim dengan beragam prestasi baik di bidang akademik dan non akademik, sudah terakreditasi $A$, serta memiliki fasilitas sarana dan prasarana sekolah yang lengkap dengan akses jaringan internet yang mendukung sehingga dapat memudahkan dalam menunjang proses pembelajaran daring. SMAN 1 Unggulan Muara Enim sudah melaksanakan pembelajaran daring sejak tahun 2020 dikarenakan adanya pandemi covid-19. Berdasarkan observasi awal di sekolah tersebut didapatkan bahwa siswa juga mengalami kejenuhan belajar dan penurunan minat belajar dalam pembelajaran daring pada pelajaran biologi. Beberapa siswa mengatakan bahwa guru tidak memberikan metode belajar yang menarik sehingga siswa merasa jenuh dan minat belajar berkurang dalam belajar. 
Padahal sebelum adanya pandemi covid-19 siswa tampak aktif dalam mengikuti kegiatan pembelajaran yang dilakukan secara tatap muka langsung disekolah. Tujuan dari penelitian ini adalah untuk menganalisis dan mengetahui faktor yang menyebabkan kejenuhan dan minat belajar siswa dalam pembelajaran daring pada pelajaran biologi di SMAN 1 Unggulan Muara Enim.

\section{METODE PENELITIAN}

Jenis penelitian yang digunakan adalah penelitian kualitatif. Tujuan dari penelitian ini adalah untuk menganalisis dan mengetahui faktor yang menyebabkan kejenuhan dan minat belajar siswa dalam pembelajaran daring pada pelajaran biologi di SMAN 1 Unggulan Muara Enim. Penelitian ini dilaksanakan pada tanggal 28 April 2021 dilaksanakan di SMAN 1 Unggulan Muara Enim. Subjek penelitian ini adalah siswa 172 siswa kelas XI MIPA dan 2 guru biologi.

Teknik pengumpulan data dalam penelitian ini melalui observasi yang dilakukan dalam penelitian melalui pengamatan pada saat kegiatan belajar mengajar pembelajaran biologi berlangsung. Pengumpulan data melalui kuesioner terbuka yang dibagikan kepada siswa kelas XI MIPA di SMAN 1 Unggulan Muara Enim menggunakan google form ketika pembelajaran daring berlangsung. Pengumpulan data melalui wawancara yaitu dilakukan peneliti kepada guru biologi secara langsung dan wawancara kepada siswa menggunakan google form di kelas XI MIPA di SMAN 1 Unggulan Muara Enim untuk mendapatkan data terkait kejenuhan dan minat belajar siswa dalam pembelajaran biologi secara daring. Pengumpulan data melalui dokumentasi yaitu berupa foto-foto kegiatan penelitian dan catatan-catatan penting dilapangan sebagai bukti fisik pelaksanaan penelitian. Dokumentasi berdasarkan data nilai ulangan harian siswa, dokumen silabus, rencana pelaksanaan pembelajaran (RPP), dan literatur yang berkaitan dengan permasalahan yang akan diteliti.

Validasi data dalam penelitian meliputi triangulasi sumber dan triangulasi teknik. Triangulasi sumber dalam penelitian ini yaitu melakukan pengecekan keakuratan data yang diperoleh melalui beberapa sumber-sumber, melalui informan yang terkait dengan subjek penelitian untuk menggali informasi secara lebih mendalam, dan melalui sumber dalam penelitian ini yaitu guru biologi, siswa kelas XI di SMAN 1 Unggulan Muara Enim. Sedangkan triangulasi teknik yaitu melakukan pengecekan keakuratan data melalui pengumpulan data yang berbeda-beda untuk mendapatkan data pengumpulan dari sumber data yang sama.

Analisis data penelitian dilakukan dalam penelitian ini menggunakan analisis Miles \& Huberman (1994) yang terdiri dari tiga tahapan, yaitu reduksi data, penyajian data, serta penarikan dan verifikasi kesimpulan. Analisis data penelitian tahap reduksi data merupakan tahapan data-data yang telah diperoleh dilapangan dicatat secara terperinci, dirangkum dan dilakukan pengelompokan pemilihan data yang dibutuhkan dan data yang tidak dibutuhkan. Tahap penyajian data merupakan tahapan data-data dalam penelitian terkumpul kemudian peneliti akan menyusun data-data tersebut secara terperinci agar data dapat mudah dilihat dan dipahami. Tahap penarikan dan verifikasi kesimpulan merupakan tahapan untuk melakukan penarikan kesimpulan atau verifikasi dari kegiatan-kegiatan sebelumnya.

Prosedur penelitian terdiri dari tiga prosedur meliputi tahap persiapan, tahap pelaksanaan, dan tahap penyelesaian. Tahapan pesiapan pada tahapan ini peneliti akan mencari informasi data awal dari berbagai sumber referensi tentang kejenuhan dan minat belajar siswa dalam pembelajaran biologi secara daring. Tahap pelaksanaan peneliti akan melaksanakan kegiatan observasi, wawancara, dokumentasi, dan membagikan lembar kuesioner. Tahap penyelesaian peneliti akan merangkum semua data yang diperoleh menggunakan teknik analisis data reduksi data, penyajian data dan penarikan kesimpulan. 


\section{HASIL PENELITIAN DAN PEMBAHASAN}

\section{Kejenuhan Belajar Siswa pada Pelajaran Biologi di SMAN 1 Unggulan Muara Enim}

Data kejenuhan belajar didapatkan melalui kuesioner, wawancara guru dan wawancara siswa. Hasil kuesioner pada pelajaran biologi yang diberikan kepada seluruh siswa kelas XI MIPA di SMAN 1 Unggulan Muara Enim berjumlah 172 namun hanya ada 164 siswa yang menjawab. Kuesioner tersebut terdiri dari 16 butir pernyataan. Faktor kejenuhan belajar siswa yang terdiri dari tiga indikator yaitu kelelahan kognitif, kelelahan emosi dan kelelahan fisik. Hasil pengisian kuesioner kejenuhan belajar siswa pada indikator kelelahan kognitif dapat dilihat pada Tabel 1.

Tabel 1. Faktor Kejenuhan Belajar Siswa pada Indikator Kelelahan Kognitif

\begin{tabular}{|c|c|c|c|c|}
\hline \multirow[t]{2}{*}{ Faktor } & \multirow[t]{2}{*}{ No } & \multirow[t]{2}{*}{ Butir Item Pernyataan } & \multicolumn{2}{|c|}{ Pilihan Jawaban } \\
\hline & & & $\mathrm{Ya}$ & Tidak \\
\hline \multirow[t]{7}{*}{ Kejenuhan Belajar } & 1. & $\begin{array}{l}\text { Saya merasa jenuh dengan banyaknya tugas yang } \\
\text { diberikan guru dalam pembelajaran daring }\end{array}$ & 148 & 16 \\
\hline & 2. & $\begin{array}{l}\text { Saya bersemangat mengikuti pembelajaran daring pada } \\
\text { pelajaran biologi }\end{array}$ & 62 & 102 \\
\hline & 3. & $\begin{array}{l}\text { Saya mengerti dengan materi yang diberikan dalam } \\
\text { pembelajaran daring pada pelajaran biologi }\end{array}$ & 78 & 86 \\
\hline & 4. & $\begin{array}{l}\text { Saya jenuh dengan metode pembelajaran yang diberikan } \\
\text { dalam pembelajaran daring }\end{array}$ & 126 & 36 \\
\hline & 8. & $\begin{array}{l}\text { Saya sering kesulitan konsentrasi dalam mengikuti } \\
\text { pembelajaran daring }\end{array}$ & 112 & 52 \\
\hline & 15. & $\begin{array}{l}\text { Saya malas mencatat materi pelajaran yang diberikan guru } \\
\text { pada pembelajaran daring }\end{array}$ & 62 & 102 \\
\hline & & & & 92 \\
\hline
\end{tabular}

Diketahui berdasarkan Tabel 1. indikator kelelahan kognitif yang terdiri dari butir item pernyataan nomor 1,2,3,4,8, dan 15 pada butir item pernyataan nomor 1 saya merasa jenuh dengan banyaknya tugas yang diberikan guru dalam pembelajaran daring. Terdapat 148 siswa menjawab "Ya"dan 16 siswa menjawab "Tidak". Siswa yang menyatakan "Ya" beralasan karena pembelajaran daring membuat dirinya merasa jenuh karena banyaknya tugas yang diberikan dan terasa sulit. Siswa tidak bisa merasakan aktivitas pembelajaran seperti disekolah, tidak bisa bertemu teman-teman, tidak bisa mengerjakan tugas kelompok sambil bercanda gurau bersama teman-teman dan melakukan kegiatan dan tugas-tugas dalam pembelajaran daring secara mandiri di rumah. Siswa yang menyatakan "Tidak" beralasan mereka tidak merasa jenuh mengikuti pembelajaran daring karena tugas-tugas yang diberikan merupakan kewajiban yang harus siswa kerjakan serta memiliki banyak waktu beristirahat dalam mengikuti pembelajaran daring.

Kejenuhan belajar siswa juga diketahui guru biologi saat pembelajaran daring. Hal ini disampaikan oleh kedua guru biologi SMAN 1 unggulan Muara Enim. Berdasarkan hasil wawancara pada pertanyaan apakah ibu mengetahui kejenuhan belajar yang dialami oleh siswa saat pembelajaran daring berlangsung? Kedua guru biologi menyatakan pendapat sama bahwa kejenuhan belajar dialami oleh siswa saat pembelajaran daring berlangsung terlihat dari lambatnya siswa merespon dan mengumpulkan tugas-tugas yang diberikan oleh guru.

Siswa juga mengalami kejenuhan akibat padatnya tugas yang diberikan oleh guru. Hal ini disampaikan oleh siswa kelas XI MIPA di SMAN 1 Unggulan Muara Enim. Berdasarkan hasil wawancara pada pertanyaan apakah padatnya tugas yang diberikan dalam pembelajaran daring membuat anda 
mengalami kejenuhan belajar? Hampir semua siswa menyatakan kejenuhan belajar dirasakan dengan padatnya tugas yang diberikan dalam pembelajaran daring. Karena tidak diimbangi dengan metode pembelajaran yang menarik dan guru tidak menjelaskan materi pembelajaran kepada siswa sehingga membuat kejenuhan dalam mengikuti pembelajaran. Sedangkan hanya sebagian siswa menyatakan padatnya tugas yang diberikan tidak merasakan kejenuhan dalam belajar karena tugas merupakan kewajiban yang harus dikerjakan.

Hal ini didukung oleh penelitian yang dilakukan (Wulandari et al., 2021), menyatakan jika faktor dari dalam diri sendiri seperti siswa kurangnya bisa mengatur waktu mengerjakan tugas secara tepat waktu dan mengerjakan tugas yang diberikan terus-menerus menyebabkan kejenuhan belajar siswa. Hal ini juga didukung oleh penelitian yang dilakukan oleh (Maghfiran, R. T, \& Hariastuti, 2020), menunjukkan jika siswa mengalami kejenuhan belajar terjadi akibat monotonnya kegiatan belajar, pembelajaran yang kurang menarik, tidak adanya interaksi langsung antara guru dan siswa lainnya karena pembelajaran dilaksanakan tanpa tatap muka sehingga menyebabkan kejenuhan belajar pada siswa. Hasil pengisian kuesioner kejenuhan belajar siswa pada indikator kelelahan emosi dapat dilihat pada Tabel 2.

Tabel 2. Faktor Kejenuhan Belajar Siswa pada Indikator Kelelahan Emosi

\begin{tabular}{|c|c|c|c|c|}
\hline \multirow[t]{2}{*}{ Faktor } & \multirow[t]{2}{*}{ No } & \multirow[t]{2}{*}{ Butir Item Pernyataan } & \multicolumn{2}{|c|}{ Pilihan Jawaban } \\
\hline & & & $\mathrm{Ya}$ & Tidak \\
\hline \multirow[t]{5}{*}{ Kejenuhan Belajar } & 5. & $\begin{array}{l}\text { Saya senang jika durasi jam belajar cukup panjang dalam } \\
\text { pembelajaran daring }\end{array}$ & 55 & 109 \\
\hline & 6. & $\begin{array}{l}\text { Saya sering menunda mengerjakan tugas yang diberikan } \\
\text { oleh guru dalam pembelajaran daring }\end{array}$ & 122 & 42 \\
\hline & 11. & $\begin{array}{l}\text { Kondisi di dalam rumah saya mendukung saya dalam } \\
\text { mengikuti pembelajaran daring }\end{array}$ & 87 & 77 \\
\hline & 14. & $\begin{array}{l}\text { Saya cemas karena sering terlambat mengumpulkan } \\
\text { tugas yang diberikan oleh guru pada pembelajarandaring }\end{array}$ & 49 & 115 \\
\hline & 16. & $\begin{array}{l}\text { Saya memiliki target nilai tinggi pada pelajaran biologi } \\
\text { tetapi saya merasa belum berusaha secara optimal }\end{array}$ & 112 & 52 \\
\hline
\end{tabular}

Diketahui berdasarkan Tabel 2 indikator kelelahan emosi yang terdiri dari butir item pernyataan nomor $5,6,11,14$, dan 16 pada butir item pernyataan nomor 6 saya sering menunda mengerjakan tugas yang diberikan oleh guru dalam pembelajaran daring. Terdapat 122 siswa menjawab "Ya" dan 42 siswa menjawab "Tidak". Siswa yang menyatakan "Ya" beralasan banyak menunda mengerjakan tugas yang diberikan oleh guru dalam pembelajaran daring. Karena waktu pengumpulan tugas yang diberikan cukup lama sehingga siswa dapat melakukan aktivitas lain terlebih dahulu di rumah. Penundaan mengerjakan tugas yang dilakukan oleh siswa tidak mempengaruhi tenggat waktu pengumpulan tugas. Siswa yang menyatakan "Tidak" beralasan karena siswa lebih memilih untuk mengerjakan tugas tepat waktu dan tidak menundanya agar tugas yang diberikan tidak menumpuk.

Pengumpulan tugas siswa tepat waktu diketahui oleh guru biologi. Hal ini disampaikan oleh kedua guru biologi SMAN 1 unggulan Muara Enim. Berdasarkan hasil wawancara pada item butirpertanyaan apakah siswa mengumpulkan tugas tepat waktu selama pembelajaran daring saat ini? Kedua guru biologi menyatakan pendapat sama jika siswa mengumpulkan tugas tepat waktu ada dan siswa yang mengumpulkan tugas kurang tepat waktu juga ada. Siswa yang terlambat mengumpulkan tugas penilaiannya berbeda dengan siswa yang cepat mengumpulkan tugas.

Siswa mengatasi juga kejenuhan dan minat belajar berkurang dalam pembelajaran daring. Hal ini disampaikan oleh siswa kelas XI MIPA di SMAN 1 Unggulan Muara Enim. Berdasarkan hasil wawancara pada pertanyaan bagaimana anda mengatasi jika mengalami kejenuhan belajar dan minat 
belajar berkurang dalam pembelajaran daring pada pelajaran biologi? Semua siswa menyatakan untuk mengatasi kejenuhan belajar dan minat belajar berkurang dalam pembelajaran daring pada pelajaran biologi yaitu dengan beristirahat sejenak, membuka media sosial, melakukan aktivitas yang menarik agar dapat menambah minat belajar kembali. Siswa melakukan aktivitas menonton video animasi yang menarik di internet tentang materi yang berkaitan dengan pelajaran biologi sehingga semangat belajar dapat muncul kembali untuk mengikuti pembelajaran daring.

Hal ini didukung oleh penelitian yang dilakukan (Safitri, R., Purnamasari, V., \& Wakhyudin, 2020), menyatakan untuk mengurangi penundaan tugas pada siswa, guru memberikan himbauan agar orang tua ikut berperan dalam memantau anak dengan menanyakan tugas-tugas yang diberikan guru sehingga dapat mengurangi penundaan tugas yang dilakukan oleh siswa. Hal ini juga didukung oleh penelitian yang dilakukan oleh (Suwarto, \& Fajri, 2018) menyatakan peran orang tua merupakan faktor penting dalam kegiatan belajar dari rumah ini. Sebaiknya orang tua memberikan perhatian lebih terhadap anak, memberi semangat dan bimbingan belajar pada anakagar anak lebih rajin untuk belajar dan tidak menunda mengerjakan tugas yang diberikan guru. Sehingga tidak menimbulkan rasa jenuh pada anak saat mengikuti pembelajaran dari rumah. Hasil pengisian kuesioner kejenuhan belajar siswa pada indikator kelelahan fisik dapat dilihat pada Tabel 3.

Tabel 3. Faktor Kejenuhan Belajar Siswa pada Indikator Kelelahan Fisik

\begin{tabular}{|c|c|c|c|c|}
\hline \multirow[t]{2}{*}{ Faktor } & \multirow[t]{2}{*}{ No } & \multirow[t]{2}{*}{ Butir Item Pernyataan } & \multicolumn{2}{|c|}{ Pilihan Jawaban } \\
\hline & & & $Y a$ & Tidak \\
\hline \multirow[t]{5}{*}{ Kejenuhan Belajar } & 7. & $\begin{array}{l}\text { Saya mudah konsentrasi saat mengikuti } \\
\text { pembelajaran daring }\end{array}$ & 53 & 111 \\
\hline & 9. & $\begin{array}{l}\text { Saya selalu tepat waktu mengikuti pembelajaran } \\
\text { daring pada pelajaran biologi }\end{array}$ & 75 & 89 \\
\hline & 10. & $\begin{array}{l}\text { Saya sering terlambat mengikuti pembelajaran daring } \\
\text { pada pelajaran biologi }\end{array}$ & 94 & 70 \\
\hline & 12. & $\begin{array}{l}\text { Saya merasa lingkungan belajar kurang kondusif } \\
\text { dirumah dalam mengikuti pembelajaran daring }\end{array}$ & 69 & 95 \\
\hline & 13. & $\begin{array}{l}\text { Badan saya terasa kurang fit banyaknya tugas yang } \\
\text { diberikan dalam pembelajaran daring }\end{array}$ & 118 & 46 \\
\hline
\end{tabular}

Diketahui berdasarkan Tabel 3 indikator kelelahan fisik yang terdiri dari butir item pernyataan nomor 7, 9, 10,12, dan 13 pada butir item pernyataan nomor 13 badan saya terasa kurang fit banyaknya tugas yang diberikan dalam pembelajaran daring. Terdapat 118 siswa menjawab "Ya" dan 46 siswa menjawab "Tidak". Siswa yang menyatakan "Ya" beralasan mengalami kelelahan yaitu dengan banyaknya tugas yang diberikan oleh guru, lamanya menatap layar laptop maupan handphone terkadang tidak mengerti dengan materi ataupun tugas yang diberikan oleh guru sehingga akhirnya siswa pun merasa pusing dan kelelahan fisik. Siswa yang menyatakan "Tidak" beralasan karena siswa beristirahat yang cukup ketika tubuh mereka merasa kelelahan dalam belajar, mengkonsumsi makanan yang bergizi dan minum vitamin agar tubuh tetap fit dalam mengikuti pembelajaran daring.

Faktor kejenuhan belajar siswa diketahui juga oleh guru biologi. Hal ini disampaikan oleh kedua guru biologi SMAN 1 unggulan Muara Enim. Berdasarkan hasil wawancara pada pertanyaan menurut ibu faktor apa saja yang menyebabkan kejenuhan belajar siswa dalam pembelajaran daring? Ibu Syamsiah, S.Pd menyatakan faktor menyebabkan kejenuhan belajar siswa dari pribadi siswa itu sendiri yang merasa sudah jenuh belajar sendiri dirumah. Sedangkan berbeda pendapat dengan Ibu Sakbaniah, S.Pd menyatakan bahwa faktor pada jaringan dan kuota internet menjadi faktor kendala kejenuhan belajar siswa. 
Siswa juga merasakan kejenuhan belajar karena adanya faktor-faktor yang mempengaruhi. Hal ini disampaikan oleh siswa kelas XI MIPA di SMAN 1 Unggulan Muara Enim. Berdasarkan hasil wawancara kepada siswa pertanyaan apakah faktor keluarga seperti peran orang tua membantu dalam mengatasi kejenuhan belajar dalam pembelajaran daring? Hampir semua siswa menyatakan faktor keluarga sangat membantu dalam mengatasi kejenuhan pembelajaran daring. Adanya peran orang tua dalam memberikan fasilitas belajar yang lengkap dirumah dan memberikan waktu refresing bersama setelah padatnya aktivitas tugas yang siswa kerjakan sehingga dapat membantu dalam mengatasi kejenuhan belajar dalam pembelajaran daring.

Hal ini didukung oleh penelitian yang dilakukan oleh (Fauziah, 2013), menyatakan jika kelelahan fisik dengan kelesuhan dalam belajar yang dialami siswa dapat dipengaruhi oleh asupan makanan yang berkurang sehingga tubuh menjadi lesu sehingga konsentrasi berpikirnya menjadi ikut berkurang dan menimbulkan rasa jenuh dalam belajar. Hal ini juga didukung oleh penelitian (Mustakim, 2020), yang menyatakan bahwa selama kegiatan pembelajaran daring siswa banyak mengalami keluhan fisik seperti mata kelelahan, sakit kepala, sering mengantuk,sulit istirahat dan keluhan fisik lainnya.

\section{Minat Belajar Siswa pada Pelajaran Biologi di SMAN 1 Unggulan Muara Enim}

Data minat belajar didapatkan melalui kuesioner, wawancara guru, dan wawancara siswa. Hasil kuesioner pada pelajaran biologi yang diberikan kepada seluruh siswa kelas XI MIPA di SMAN 1 Unggulan Muara Enim berjumlah 172 terdapat 164 siswa yang menjawab kuesioner yang diberikan yang terdiri dari 14 butir pernyataan. Terdapat faktor minat belajar siswa yang terdiri dari empat indikator yaitu: perasaan senang, perhatian, keterlibatan, dan ketertarikan. Berikut ini faktor minat belajar siswa pada indikator perasaan senang dapat dilihat pada Tabel 4.

Tabel 4. Faktor Minat Belajar Siswa pada Indikator Perasaan Senang

\begin{tabular}{ccccc}
\hline Faktor & No & Butir ltem Pernyataan & \multicolumn{2}{c}{ Pilihan Jawaban } \\
\cline { 3 - 4 } & 1. & $\begin{array}{l}\text { Pada pembelajaran daring saya lebih minat } \\
\text { pelajaran biologi }\end{array}$ & 102 & Tidak \\
\hline 2. & $\begin{array}{l}\text { Biologi lebih mudah saya pahami dalam } \\
\text { pembelajaran daring } \\
\text { 8. }\end{array}$ & $\begin{array}{l}\text { Saya lebih suka pelajaran biologi dengan tatap } \\
\text { muka dari pada pembelajaran daring } \\
\text { Adanya pembelajaran daring membuat saya } \\
\text { semangat belajar }\end{array}$ & 151 & 77 \\
& 11. & 43 & 121 \\
\hline
\end{tabular}

Diketahui berdasarkan indikator perasaan senang yang terdiri dari butir item pernyataan nomor 1, 2, 8, dan 11 pada butir item pernyataan nomor 8 saya lebih suka pelajaran biologi dengan tatap muka dari pada pembelajaran daring. Terdapat 151 siswa menjawab "Ya" dan 13 siswa menjawab "Tidak". Siswa yang menyatakan "Ya" beralasan karena dengan adanya tatap muka maka akan ada interaksi kepada guru dan bisa bertanya jika ada materi pelajaran yang kurang dimengerti pada saat itu juga. Sehingga siswa lebih suka pelajaran biologi dengan tatap muka dari pada pembelajaran daring. Siswa yang menyatakan "Tidak" beralasan karena mereka lebih suka pembelajaran daring karena dengan pembelajaran daring mereka lebih dapat leluasa mendapatkan pokok materi yang sedang siswa pelajari secara mandiri dan memiliki banyak waktu luang dirumah.

Guru mempunyai harapan dalam pembelajaran daring pada pelajaran biologi. Hal ini disampaikan oleh siswa kelas XI MIPA di SMAN 1 Unggulan Muara Enim. Berdasarkan hasil wawancara pada pertanyaan bagaimana harapan ibu dalam pembelajaran daring khususnya pada pelajaran biologi? Kedua guru menyatakan pendapat sama bahwa harapan kedepannya agar pembelajaran daring dapat 
dilakukan secara tatap muka karena sebagai guru tidak puas jika tidak memberikaan penjelasan secara langsung keada siswa. Siswa juga mengalami kejenuhan belajar dengan metode pembelajaran daring yang diberikan oleh guru. Hal ini disampaikan oleh siswa kelas XI MIPA di SMAN 1 Unggulan Muara Enim. Berdasarkan hasil wawancara kepada siswa pada pertanyaan apakah metode pembelajaran daring yang telah diberikan oleh guru pada pelajaran biologi membuat menarik belajar anda? Hampir semua siswa menyatakan metode pembelajaran daring yang telah diberikan oleh guru pada pelajaran biologi kurang menarik karena guru hanya memberikan materi tanpa menjelaskan secara rinci dan pemberian tugas saja sehingga membuat siswa tidak bersemangat dalam belajar dan malas mengikuti pembelajaran daring. Hasil pengisian kuesioner kejenuhan belajar siswa pada indikator perhatian dapat dilihat pada Tabel 5.

Tabel 5. Faktor Minat Belajar Siswa pada Indikator Perhatian

\begin{tabular}{|c|c|c|c|c|}
\hline \multirow[t]{2}{*}{ Faktor } & \multirow[t]{2}{*}{ No } & \multirow[t]{2}{*}{ Butir Item Pernyataan } & \multicolumn{2}{|c|}{ Pilihan Jawaban } \\
\hline & & & $\mathrm{Ya}$ & Tidak \\
\hline \multirow[t]{4}{*}{ Minat Belajar } & 3. & $\begin{array}{l}\text { Saya mengerjakan tugas yang diberikan oleh guru } \\
\text { dalam pembelajaran daring }\end{array}$ & 164 & 0 \\
\hline & 5. & $\begin{array}{l}\text { Saya memusatkan perhatian dan pikiran pada } \\
\text { pelajaran biologi }\end{array}$ & 50 & 114 \\
\hline & 6. & $\begin{array}{l}\text { Saya menyimak penjelasan guru pada saat } \\
\text { memberikan materi dalam pembelajaran daring }\end{array}$ & 154 & 10 \\
\hline & 13. & $\begin{array}{l}\text { Saya jarang bertanya kepada guru dalam } \\
\text { pembelajaran daring pada pelajaran biologi }\end{array}$ & 146 & 18 \\
\hline
\end{tabular}

Diketahui berdasarkan indikator perhatian yang terdiri dari butir item pernyataan nomor 3, 5, 6, dan 13 pada butir item pernyataan nomor 3 saya mengerjakan tugas yang diberikan oleh guru dalam pembelajaran daring. Terdapat seluruh siswa menjawab 164 "Ya". Siswa yang menyatakan "Ya" beralasan mereka mengerjakan tugas selama pembelajaran daring karena itu adalah kewajiban sebagai siswa walaupun belajarnya secara daring untuk mendapat nilai raport yang optimal.

Minat belajar siswa dalam pembelajaran daring diketahui oleh guru biologi. Hal ini disampaikan oleh kedua guru biologi SMAN 1 unggulan Muara Enim. Berdasarkan hasil wawancara pada pertanyaan bagaimana untuk mengetahui tentang minat belajar siswa dalam pembelajaran biologi? Kedua guru biologi menyatakan pendapat sama bahwa untuk mengetahui tentang minat belajar siswa dalam pembelajaran biologi terlihat dari cepat dan tidaknya siswa merespon serta mengumpulkan tugas yang guru berikan dengan rapi misalnya, ketika ada kesulitan dalam belajar siswa bertanya kepada guru sehingga terlihat minat belajar siswa juga dalam mengerjakan tugas-tugas yang diberikan oleh guru.

Aplikasi dalam pembelajaran daring membantu meningkatkan minat belajar siswa. Hal ini disampaikan oleh siswa kelas XI MIPA di SMAN 1 Unggulan Muara Enim. Berdasarkan hasil wawancara pada pertanyaan apakah aplikasi yang digunakan dalam pembelajaran daring pada pelajaran biologi efektif? Hampir semua siswa menyatakan cukup efektif aplikasinya yang digunakan seperti google classroom pun cukup mudah digunakan dan dipahami untuk siswa mengerjakan tugas yang diberikan oleh guru. Sedangkan sebagian siswa yang menyatakan untuk pengerjaan tugas sudah efektif tetapi dalam hal penyampaian materi dalam pelajaran biologi menurut saya kurang efektif karena guru tidak menjelaskan materi pembelajarannya kepada siswa.

Berdasarkan penelitian terdahulu yang dilakukan oleh (Handayani, 2020) menunjukkan beberapa siswa mengatakan bahwa siswa lebih senang pembelajaran tatap muka dapat mendengarkan pertanyaan dan umpan balik dalam belajar yang diberikan oleh guru secara langsung. Hal ini didukung juga penelitian 
terdahulu oleh (Purwanto, A., Pramono, R., dan Asbari, 2020) menyatakan penyampaian materi tidak jelas, adanya kejenuhan dan suasana yang monoton kurangnya interaksi siswa dengan guru sehingga siswa lebih senang belajar tatap muka. Hasil pengisian kuesioner kejenuhan belajar siswa pada indikator keterlibatan dapat dilihat pada Tabel 6.

Tabel 6. Faktor Minat Belajar Siswa pada Indikator Keterlibatan

\begin{tabular}{|c|c|c|c|c|}
\hline \multirow[t]{2}{*}{ Faktor } & \multirow[t]{2}{*}{ No } & \multirow[t]{2}{*}{ Butir Item Pernyataan } & \multicolumn{2}{|c|}{ Pilihan Jawaban } \\
\hline & & & $\mathrm{Ya}$ & Tidak \\
\hline \multirow[t]{4}{*}{ Minat Belajar } & 4. & $\begin{array}{l}\text { Pembelajaran daring membuat minat saya } \\
\text { berkurang pada pelajaran biologi }\end{array}$ & 57 & 107 \\
\hline & 7. & $\begin{array}{l}\text { Saya sering terlambat mengisi daftar hadir dalam } \\
\text { pembelajaran daring }\end{array}$ & 35 & 129 \\
\hline & 10. & $\begin{array}{l}\text { Saya langsung meminta jawaban kepada teman } \\
\text { dan langsung menyalinnya ketika materi tugas } \\
\text { biologi dirasakan sulit }\end{array}$ & 31 & 133 \\
\hline & 14. & $\begin{array}{l}\text { Saya senang ketika guru membatalkan ulangan } \\
\text { harian dalam pembelajaran daring }\end{array}$ & 69 & 95 \\
\hline
\end{tabular}

Diketahui berdasarkan indikator keterlibatan yang terdiri dari butir item pernyataan nomor 4, 7, 10 , dan 14 pada butir item pernyataan nomor 14 saya senang ketika guru membatalkan ulangan harian dalam pembelajaran daring. Terdapat 69 siswa menjawab "Ya"dan 95 siswa menjawab "Tidak". Siswa yang menyatakan "Ya" beralasan karena mereka senang jika ulangan diundur mereka bisa memiliki banyak waktu untuk belajar dan mempersiapkan diri untuk menghadapi ulangan nantinya. Siswa yang menyatakan "Tidak" beralasan karena mereka tidak ingin jika ulangan diundur. Jika ulangan diundur maka mereka harus belajar kembali pada keesokan harinya.

Guru sudah berusaha menumbuhkan minat belajar siswa dalam pembelajaran biologi. Hal ini disampaikan oleh kedua guru biologi SMAN 1 unggulan Muara Enim. Berdasarkan hasil wawancara pada pertanyaan bagaimana ibu menumbuhkan minat belajar siswa? Kedua guru biologi menyatakan pendapat sama bahwa untuk menumbuhkan minat belajar siswa yaitu dengan memberikan motivasimotivasi belajar pada siswa untuk menumbuhkan minat belajar siswa serta mengingatkan siswa yang belum mengumpulkan tugas untuk segera mengumpulkan tugas dengan tepat waktu.

Siswa juga membangkitkan semangat dan minat belajar dalam pembelajaran daring. Hal ini disampaikan oleh siswa kelas XI MIPA di SMAN 1 Unggulan Muara Enim. Berdasarkan hasil wawancara pada bagaimana membangkitkan semangat belajar dan minat belajar anda dalam mengikuti pembelajaran daring? Hampir semua siswa menyatakan membangkitkan semangat belajar dan minat belajar dalam mengikuti pembelajaran daring yaitu dengan mendengarkan musik, membaca motivasimotivasi sukses dan membagi waktu yang cukup antara belajar dan istirahat.

Hal ini didukung oleh penelitian yang dilakukan (Rudiansyah, Amirullah, dan Yunus, 2016) menyatakan jika rasa tidak percaya diri siswa mengikuti ulangan menimbulkan rasa cemas dan rasa takut tidak bisa mendapatkan nilai yang optimal. Sehingga siswa harus bersikap tenang dan mempersiapkan diri ketika akan menghadapi ulangan agar mendapatkan hasil nilai yang optimal. Hal ini juga didukung oleh penelitian yang dilakukan oleh (Apriyanto \& Herlina, 2020) menyatakan jika siswa diharapkan untuk selalu siap dalam mengikuti pembelajaran daring maupun ulangan yang diberikan guru dalam keadaan apapun karena keberhasilan belajar daring didukung oleh strategi guru dalam mengolah materi ajar dan 
informasi semenarik mungkin dan mudah untuk dipahami. Hasil pengisian kuesioner kejenuhan belajar siswa pada indikator ketertarikan dapat dilihat pada Tabel 7.

Tabel 7. Faktor Minat Belajar Siswa pada Indikator Ketertarikan

\begin{tabular}{cclcc}
\hline Faktor & No & Butir Item Pernyataan & \multicolumn{2}{c}{ Pilihan Jawaban } \\
\cline { 3 - 5 } & & & Ya & Tidak \\
\hline Minat Belajar & 9. & $\begin{array}{l}\text { Saya selalu mencari jawaban di internet saat ada } \\
\text { soal yang sulit dikerjakan }\end{array}$ & 153 & 11 \\
& 12. & $\begin{array}{l}\text { Saya belajar biologi ketika akan menghadapi ujian } \\
\text { Saya jarang bertanya kepada guru dalam } \\
\text { pembelajaran daring pada pelajaran biologi }\end{array}$ & 99 & 65 \\
& 13. & 146 & 18 \\
\hline
\end{tabular}

Diketahui berdasarkan indikator ketertarikan yang terdiri dari butir item pernyataan nomor 9,12 , dan 13 pada butir item pernyataan nomor 9 saya selalu mencari jawaban di internet saat ada soal yang sulit dikerjakan. Terdapat 153 siswa menjawab "Ya" dan 11 siswa menjawab "Tidak". Siswa yang menyatakan "Ya" beralasan karena siswa sudah berusaha mencari jawaban tugas dari buku maupun dari materi yang di berikan namun tidak menemukan jawaban sehingga siswa mencari solusi mencari jawaban dari tugas yang diberikan guru melalui internet. Siswa yang menyatakan "Tidak" beralasan karena siswa keterbatasan kuota internet sehingga mereka mencari jawaban tugas melalui buku paket dan LKS yang mereka miliki.

Faktor berkurangnya minat belajar siswa juga diketahui oleh guru biologi. Hal ini disampaikan oleh siswa kelas XI MIPA di SMAN 1 Unggulan Muara Enim. Berdasarkan hasil wawancara pada pertanyaan menurut ibu apakah faktor yang membuat minat belajar siswa berkurang? Kedua guru biologi menyatakan pendapat sama bahwa bahwa faktor berkurangnya minat siswa juga terlihat dari faktor individu siswa itu sendiri seperti siswa mengerjakan sendiri tugas-tugasnya tanpa adanya teman diskusi, kendala terhadap jaringan yang kadang tidak stabilnya dan faktor keluarga seperti kurangnya perhatian keluarga terhadap aktivitas kegiatan belajar yang dilakukan oleh siswa dirumah.

Siswa juga merasakan jika smartphone yang digunakan dapat membantu dalam mengikuti pembelajaran daring. Hal ini disampaikan oleh siswa kelas XI MIPA di SMAN 1 Unggulan Muara Enim. Berdasarkan hasil wawancara pada pertanyaan apakah smartphone atau laptop yang telah digunakan dapat membantu dalam mengikuti pembelajaran daring dengan baik? Semua siswa menyatakan jika smartphone atau laptop yang digunakan dapat membantu dalam mengikuti pembelajaran daring dengan baik. Terutama membantu untuk mendownload aplikasi pembelajaran yang memudahkan siswa untuk mengikuti pembelajaran daring dan mengerjakan tugas yang diberikan oleh guru.

Hal ini didukung oleh penelitian yang dilakukan (Tondang, Y.S dan Arwita, 2020) menyatakan bahwa pemanfaatan smartphone dapat mendukung kegiatan pembelajaran seperti ketika siswa menerima materi yang diberikan guru yang belum dipahami siswa. Sumber internet dapat membantu siswa untuk memahami materi yang belum dipahami dan mencari jawaban tugas yang diberikan guru. Hal ini juga didukung oleh penelitian (Sasmita, 2020) menyatakan bahwa adanya internet dapat membantu siswa untuk mendapatkan informasi pembelajaran sebanyak-banyaknya sehingga siswa dapat dengan cepat mendapatkan sumber dalam belajar.

\section{SIMPULAN}

Kejenuhan dan minat belajar siswa dalam pembelajaran daring pada pelajaran biologi di SMAN 1 Unggulan Muara Enim dirasakan oleh siswa-siswi di sekolah SMAN 1 Unggulan Muara Enim. Hasil 
penelitian faktor kejenuhan belajar siswa yang terdiri dari tiga indikator yaitu kelelahan kognitif, kelelahan emosi dan kelelahan fisik menunjukkan jika siswa mengalami kejenuhan dalam proses pembelajaran dikarenakan metode pembelajaran yang diberikan oleh guru tidak menarik. Sedangkan pada hasil penelitian faktor minat belajar siswa yang terdiri dari empat indikator yaitu perasaan senang, perhatian, keterlibatan, dan ketertarikan menunjukkan jika banyaknya siswa yang mengerjakan dan mengumpulkan tugas yang diberikan oleh guru. Hal ini menunjukkan jika kondisi kejenuhan belajar yang dirasakan oleh siswa tidak menurunkan minat belajar siswa dalam mengikuti pembelajaran daring di SMAN 1 Unggulan Muara Enim.

\section{UCAPAN TERIMA KASIH}

Terima kasih kepada Allah SWT yang memberikan kemudahan dan kelancaran pada saat penulisan artikel, kepada Dr. Sri Wardhani, M.Si dan Dr. Astrid S.W. Sumah, M.Si yang telah membimbing. Kepada kepala sekolah serta guru SMAN 1 Unggulan Muara Enim yang mengizinkan untuk melakukan penelitian di sekolah tersebut. Ucapan terima kasih juga kepada pihak-pihak yang sudah mendukung dan mensuport untuk menyelesaikan penelitian ini.

\section{RUJUKAN}

Anugrahana, A. (2020). Hambatan, Solusi dan Harapan: Pembelajaran Daring Selama Masa Pandemi Covid-19 Oleh Guru Sekolah Dasar. Scholaria: Jurnal Pendidikan Dan Kebudayaan, 10(3), 282289. https://doi.org/10.24246/j.js.2020.v10.i3.p282-289

Apriyanto, M. T., \& Herlina, L. (2020). Analisis Prestasi Belajar Matematika pada Masa Pandemi Ditinjau dari Minat Belajar Siswa. Seminar Nasional Dan Diskusi Panel Pendidikan Matematika, 135-144. http://proceeding.unindra.ac.id/index.php/DPNPMunindra/article/view/4774

Arifa. F. N. (2020). Tantangan Pelaksanaan Kebijakan Belajar Dari Rumah Dalam Masa Darurat Covid19. Info Singkat; Kajian Singkat Terhadap Isu Aktual Dan Strategis, 7(6).

http://berkas.dpr.go.id/puslit/files/info_singkat/InfoSingkat-XII-7-I-P3DIApril2020-1953.pdf

Berutu, M. H. A., \& Tambunan, M. I. H. (2018). Pengaruh Minat Dan Kebiasaan Belajar Terhadap Hasil Belajar Biologi Siswa Sma Se-Kota Stabat. Jurnal Biolokus, 1(2), 109. https://doi.org/10.30821/biolokus.v1i2.351

Damayanti, A., Suradika, A., \& Asmas, B. (2020). Strategi Mengurangi Kejenuhan Anak Dalam Pembelajaran Jarak Jauh ( PJJ) melalui Aplikasi ICANDO pada Siswa Kelas I SDN Pondok Pinang 08 Pagi. Seminar Nasional Penelitian LPPM UMJ, 1-10. http://jurnal.umj.ac.id/index.php/semnaslit

Dewi, R. P., Yosef, \& Harlina. (2017). Hubungan Antara Academic Self-Confidence Dengan Kejenuhan (Burnout) Belajar Siswa SMK Negeri 1 Indralaya Utara. Konseling Komprehensif, 4(2), 14-27.

Fauziah, N. (2013). Faktor Penyebab Kejenuhan Belajar Sejarah Kebudayaan Islam (SKI) pada Siswa Kelas XI Jurusan Keagamaan di MAN Tempel Sleman. 10(1), 99-108.

Handayani, L. (2020). Keuntungan, Kendala dan Solusi Pembelajaran Online Selama Pandemi Covid-19. Studi Ekploratif, 1(2), 15-23. https://doi.org/https://doi.org/10.7777/jiemar.v1i2

Isfahani, F. R. Al, Sutijono, S., \& Farid, D. A. M. (2021). Traditional play therapy "Bancakan" efektif dalam mengurangi kejenuhan pembelajaran daring siswa SMA saat pandemi Covid-19. Teraputik: Jurnal Bimbingan Dan Konseling, 5(1), 77-86.

https://doi.org/10.26539/teraputik.51604

Kurnia, D. (2021). Dinamika Gejala Kejenuhan Belajar Siswa pada Proses Belajar Online Faktor Faktor yang Melatarbelakangi dan Implikasinya pada Layanan Bimbingan Keluarga (Penelitian Terhahap Siswa Kelas VIII MTS Negeri 3 Bandung Tahun Pelajaran 2020/2021). TEACHING : Jurnal Inovasi Keguruan Dan Ilmu Pendidikan, 1(1), 50-56. 
Maghfiran, R. T, \& Hariastuti, R. T. (2020). Hubungan Antara Penyesuaian Diri Pembelajaran Daring dengan Burnout pada Siswa SMA di Kabupaten Tulungagung Masa Pandemi Covid-19. Universitas Negeri Surabaya.

Malyana, A. (2020). Pelaksanaan Pembelajaran Daring dan Luring dengan Metode Bimbingan Berkelanjutan ada Guru Sekolah Dasar di Teluk Betung Utara Bandar Lampung. 2(1), 67-76.

Mustakim. (2020). Efektivitas Pembelajaran Daring Menggunakan Media Online Selama Pandemi Covid19 Pada Mata Pelajaran Matematika. Al Asma: Journal of Islamic Education, 2 (1), 1-12. https://doi.org/10.24252/asma.v2i1.13646

Purwanto, A., Pramono, R., dan Asbari, M. (2020). Studi Eksploratif Dampak Pandemi COVID-19 Terhadap Proses Pembelajaran Online di Sekolah Dasar. 2 (1), 1-12.

Ricardo \& Meilani, R. I. (2017). Impak Minat dan Motivasi Belajar Terhadap Hasil Belajar Siswa. Jurnal Pendidikan Manajemen Perkantoran, 2 (2), 79. https://doi.org/10.17509/jpm.v2i2.8108

Rudiansyah, Amirullah, dan Yunus, M. (2016). Upaya Guru Dalam Mengatasi Kecemasan Siswa Dalam Menghadapi Tes (Pencapaian Hasil Belajar) Siswa Di Smp Negeri 3 Banda Aceh. 1(1), 96-109.

Safitri, R., Purnamasari, V., \& Wakhyudin, H. (2020). Dampak Game Online PUBG Terhadap Perilaku Prokrastinasi Siswa. Ejournal.Undiksha.Ac.Id, 4 (1), 30-38. https://ejournal.undiksha.ac.id/index.php/IJNSE/article/view/29079

Sasmita, R. S. (2020). Pemanfaatan Internet Sebagai Sumber Belajar. Jurnal Pendidikan Dan Konseling, 2 (2), 99-103.

Sirait, E. D. (2016). Pengaruh Minat Belajar Terhadap Prestasi Belajar Matematika. Formatif: Jurnal IImiah Pendidikan MIPA, 6 (1), 35-43. https://doi.org/10.30998/formatif.v6i1.750

Suwarto, \& Fajri, H. (2018). Persepsi Orang Tua Terhadap Proses Bimbingan Belajar Anak Di Rumah. SAP (Susunan Artikel Pendidikan), 3(1). https://doi.org/10.30998/sap.v3i1.2735

Tanjung, R., Ritonga, T., \& Siregar, E. Y. (2021). Analisis Minat Belajar Siswa Dalam Pembelajaran Daring Pada Masa Pandemi Covid-19 Di Desa Ujung Batu Barus. MathEdu (Mathematic Education Journal), 4 (1), 88-96. http://journal.ipts.ac.id/index.php/MathEdu

Tondang, Y.S dan Arwita, W. (2020). Pemanfaatan Internet Sebagai Sumber Pembelajaran Biologi. Jurnal Pelita Pendidikan, 8 (2), 151-159.

Widiantika, I., \& Munandar, D. R. (2021). Analisis Minat Belajar Daring Matematika. 4(2), 425-434. https://doi.org/10.22460/jpmi.v4i2.425-434

Wulandari, I., Fatimah, S., \& Suherman, M. M. (2021). Gambaran Faktor Penyebab Prokrastinasi Akademik Siswa SMA Kelas pada Masa Pandemi Covid-19. Fokus, 4(3), 200-212. 